\title{
THE IMPACT OF CULTURE, EDUCATION AND ENVIRONMENT ON WOMEN ENTREPRENEURSHIP: A COMPARATIVE STUDY OF PERCEPTIONS OF YOUNG FEMALES IN INDIA
}

\author{
Dr. Nilam Panchal
}

\begin{abstract}
Our Youths presently live in an environment predominant with the influences of parents, schools, peer groups, government policies, social values and the wave of internet related issues. All these work to shape the thinking and direction of our youths positively or negatively. In the positive sense, the mind and thought of these youths become properly and positively directed to face the issues of life, while the reverse becomes the opposite. The need to create value in the lives of our Youths special young women has given rise to various calls for inculcating entrepreneurship skills amongst them. Since women entrepreneurship involves wealth creation leading to gainful employment and advancing society, the need therefore to strengthen entrepreneurship programmes. We are aware that if the youth women are mobilized to embrace entrepreneurship it would go a long way to reduce societal crimes like armed robbery, kidnapping, drug abuse, immoral behaviours etc. The need of the day is to develop culture. The objectives of the study are to study the entry barriers to entrepreneurship as perceived by the young women in Gujarat. To analyze the career preference and its influencing factors of the women under study in Gujarat. To explore the perception about the possible support system required by the young women for the establishment of entrepreneurship in the areas under study. To study the awareness of policies, programmes, institutional networks and support agencies in promoting women's entrepreneurship in Gujarat. The research design is descriptive in nature. Data will be collected through a self structured questionnaire. Data has been analyzed using various techniques and tools of research. Data has been analyzed and interpreted with the help of $\mathrm{R}$ Software. The study here concentrates on measuring impact of culture, education and environment on the on women entrepreneurship. Due to government efforts to empower women, they have reached a good level but does that lead to realization of better opportunities and does
\end{abstract}


result it in better efficient way. The study focuses upon collecting data from different parts of country and try to bring out social challenges and other challenges of our country.

Key words : Women Entrepreneurship, Empowerment, Youth, Women leader

\section{INTRODUCTION}

Women, when we think of, are now considered at par and women have also been given equal importance to the society. The involvement of women by government, private and public organizations, societies, seems to be equal but if we compare to entrepreneurship ventures taken up by men and women in our society, we find wide variations. Culture, educational levels, and environment in which we live varies from region to region and has a great impact upon the belief and perception regarding career preferences and thus towards entrepreneurship too. Gujarat located on the western coastal of India, has 33 districts. The population of India has reached more than 1.21 Billion, from which Gujarat has 6.03 crore which is approximately $4.99 \%$ of the total population of our country. From the total population Females in Gujarat are around 2.9 crores. Gujarat was $79.31 \%$ as per 2011 population Census. Of that Male literacy stands at $87.23 \%$ while female literacy is at $70.73 \%$ of total Indian population. Despite several steps by government of Gujarat on economic and social empowerment of women with protection to Women from Domestic Violence, Rights of Property by female members, Dowry Prohibition, Protection from sexual harassment, indecent representation of women and many other women favoring actions etc., the motivation of women towards starting an enterprise is very low. Compare to Madhya Gujarat, North and South Gujarat are the regions where there is less women entrepreneurs. The question comes is what are the perceptions of young women behind these developments? Why young women in Gujarat are not putting steps towards entrepreneurship? In a pilot study of 200 young females, from south Gujarat only 4,7 in North Gujarat and 2 from West Gujarat are interested for entrepreneurship. The question is to study why this is happening? Thus this study gives emphasis on identifying the perception of the barriers to being an entrepreneur by the young women in the Gujarat.

\section{LITERATURE REVIEW}


P. Babu (1978) made an attempt to find out the sociological factors that contribute to the development of small entrepreneurs .The study showed that community and family background contributed to the success of prospective entrepreneurs. Formal education has not been a positive factor in entrepreneurship development and at the same time providing infrastructure facilities alone will not promote entrepreneurship development. Margaret Meaning and Anne Jardim (1979) conducted the study of women at managerial position by analyzing the life and career history of twenty-five women at the top management position in business and industry. The study reveals that women can build extremely successful management careers even without legal pressures to aid them. The study further reveals the price they paid -their personal lives were mortgaged to pay for their careers. Maintaining work life balance is one of the most important traits for women entrepreneurs as they also have a family to run, kids to be looked after. Aruna Shree P Rao (1981) made a study on the level of organizational involvement of women in development projects. The study recommends that project personnel should train participants in the skills necessary for planning and implementing project activities and Project should concentrate on activities designed to raise the income of the participants. The need for competencies for project development is to be horned and the policies of the government help to do the same through various agencies like Mitcon for development of entrepreneurial project ventures.

Theories of entrepreneurial intention and perception include Ajzen and Fishbein's 1975 theory of reasoned behaviour, Shapero and Sokol's entrepreneurial event theory of 1982 and Bandura's process driven theory of 1986 .Ajzen and Fishbein's (1975) theory of reasoned action declare that behaviour is greatly influenced by one's intention to engage in that behaviour and intentions are influenced by attitude towards the behaviour. This implies that intention comes first before the actual behaviour. The underlying assumptions of this theory are that:

- Much human behaviour is planned and therefore preceded by intention towards that behaviour. 
- Human beings are rational and make systematic use of information available to them when making decisions.

- Intention predicts planned behaviour

Shapero and Sokol (1982) introduced the entrepreneurial event theory. The theory examines life path changes and their impact on individual desirability and perceptions of feasibility related to new venture formation. The underlying assumption of the entrepreneurial event theory is that, critical life changes (displacement) precipitate a change in entrepreneurial intention and subsequent behaviour. Displacement can occur in a negative form such as job loss or a positive form such as financial support. The intention to become an entrepreneur therefore depends on the individual perceptions of desirability and feasibility in relation to that activity. Shapero and Sokol (1982) also distinguished push and pull factors to entrepreneurial intentions. Positive factors like market opportunities pull people towards an entrepreneurial venture; while negative factors, necessity related events like unemployment or frustration with current job, may push people to self employment.

Another theory of entrepreneurial intention is the process driven theory developed by Bandura in1986. Bandura explained that behaviour is dependent on an individual's perception that they can carry out the intended action. According to the process driven theory, external environment influences thoughts, which shape attitude and form intention, which if strong enough leads one to action.

Besides, newer reviews and evaluations of entrepreneurship personality research suggest that personality traits of entrepreneurs may be important for entrepreneurship. Several scholars have thoroughly studied the barriers in developed countries (Collins, Hanges and Locke, 2004; 
Kwong, Jones-Evans and Thompson, 2012). The research on entrepreneurship in developing countries has not very well been investigated (Nabi and Linan, 2011; Sandhu, Sidique and Riaz, 2011). There is a lack of research in the field of graduate entrepreneurship in the developing world, and further research in developing countries may help to understand the entrepreneurial venturing issues (Sandhu et al., 2011). It is perceived by the youths that there is high level of barriers to entrepreneurship (Sharma and Madan, 2013)

Kunene (2008) has identified elements in the macro environment such a economic factors, political-institutional factors, socio-cultural factors, market environment, internal environment such as company demographics and human capital as the primary barriers or at least perceived barriers for Small Micro and Medium Enterprise. Taormina and Lao (2007) found that budding and aspirant entrepreneurs face psychological issues in entrepreneurial venturing; Sandhu et al. (2011) suggest that variables like fear of failure, lack of social circle, avoidance of risk and lack of resources affect entrepreneurship. Chowdhury (2007) explains that political instability, corruption, lack of infrastructure facilities, proper education and training and lack of financial help are barriers to entrepreneurship in developing nations.

Young people's engagement in entrepreneurship helps them to achieve economic independence and reduce their reliance on state welfare. Youth entrepreneurship brings about self esteem and makes the youths more productive members of their families and communities. Youth entrepreneurship brings about growth in an economy in that, by providing employment, the employees and the business would pay taxes thus contributing to government revenue. Entrepreneurship including youth entrepreneurship improves the general standard of society as a whole, which leads to political stability and national security. Youth entrepreneurship reduces 
crime, poverty and income inequality. This indirectly induces an environment for national and regional economic growth and development. Thus, an investigation of the perception of the youths of NER of India about the possible barriers to entrepreneurship development is essential. This study focuses on the youths in the Colleges, Institutes and Universities.

Annie Phizakka (1988) Entrepreneurship can be seen as a form of disguised unemployment. It was pointed out that self-employment is not necessarily synonymous with entrepreneurship. In many self employment units the 'boss' manages and controls the affairs with no paid employees, very often, family members constitute the work force, without having the status of an employer. UshaJumani (1991) conducted a study to analyze the status of selfemployedwomen in rural areas. Economic activities through which the income of the women will be increased have to be identified with great care. They have to be in consonance with time availability with family roles and with their awareness levels. Traditional occupations can be exchanged for the new technological based employment for women entrepreneurs. Use of Information technology and also scientific processes, can enhance economic activities in the rural area.The women need to be trained by the government for the same.Polices that encourage the training through government agencies can cover both male as well as the female business contenders.

The influence of the role of entrepreneurship on economic development has been explained by a number of authors (e.g. Audretsch and Acs, 2003; Reynolds, 2000). Conditioned by a number of forces and factors (incl. legal, institutional, cultural, societal etc.), the role of entrepreneurship has been different across countries. In a report of the World Bank (2008), it was written very clearly that there are many crucial factors for the entrepreneurial engagement. It includes: promoting an entrepreneurial culture among young people, improving entrepreneurial education, improving access to finance, improving the administrative and regulatory framework, business assistance and development services, and improving youth entrepreneurship policy.

Naqshbandi (2004) in his article on women entrepreneurship affirms that the entry of women in the field of entrepreneurship in Asia and Africa is constrained by a large number of 
barriers and challenges. Contextualizing the basic framework of El Namaki \& Gerritson (Birley, 1988), he identifies these challenges under seven categories:

1.Barriers of infrastructure such as access to credit, access to technology, support and guidance, information on opportunities, government support, industrial support and financial support (for raising capital);

2. Professional barriers such as traditional occupational restrictions, lack of professional education, generating skill, and knowledge of industrial collaboration;

3.Educational and training barriers such as vocational training opportunities, lack of information/ advice on how to start an enterprise, basic educations, and no time for training/ upgrading skills;

4. Social and cultural barriers such as values and family structure, combining family and work life, and gender bias;

5. Legal barriers such as discrimination in acting independently and assuming responsibility;

6. Behavioral constraints such as self-confidence, finding the right contacts for your business ventures, gaining of acceptance/ respect of people, and the negative image of self; and

7. Barriers of role: leadership requirements, compatibility with tasks, and the pressures to achieve.

Pretorius and Shaw (2004) and Atieno (2009) report that lack of finance is one of the major constraints to the formation of new enterprises. Entrepreneurs need to access to both internal and external finance to reduce the survive and grow. According to Lefebvre and Lefebvre (2002) and Peterman and Kennedy (2003) managerial competency and skills are important for new firm formation. Robertson, Collins, Medeira and Slatter (2003) and Bosma, Van Praag, Thurnik and De Wit (2004) find that the endowed level of talent of a small business founder is the investment in industry-specific and entrepreneurship-specific human capital which contributes significantly 
to the performance of new small firm. The quality and context of the educational system do not promote the development of managerial competencies.

Social and cultural factors can also have an influence on youth latent entrepreneurial intention. Chigunta (2002) found evidence from developing countries that participation of youths varies with gender and young men are more likely to be self employed than young women. These findings appear to suggest the existence of socio-cultural constraints which tend to affect the participation rate of young women. Morrison, (2000) has emphasized that cultural factors such as social norms can influence the way entrepreneurs perceive opportunities and this could represent significant barriers.

In addition, most potential entrepreneurs are not aware of government programmes specifically designed to help them. Lack of awareness of the existence of Government programmes is another problem faced by youth. Most youths are not aware of the various support programmes available and as a result, youths with entrepreneurial tendencies perceive that there is no support from government. One of the barriers to the success of an enterprise is lack of willingness to take risk. Fear of failure and embarrassment prevent people with ideas not to explore them and venture into a competitive stage. Many young entrepreneurs become risk averse because of their social environment (Kazela, 2009).

If youths have negative perception regarding the environment of the business, they might decide not to start their own business. Mollentz (2002) affirm that market issues and demand for products are the most important factors that positively influence new enterprises growth. Thus, bad market conditions and no market opportunities can be a constraint to youth entrepreneurial intention. 
The rising number of female business owners is, currently, a global trend. In advanced market economies, women own more than $25 \%$ of all businesses (Woldie\&Adersua, 2004). Walker et al. (2007) argue that historically women were "pushed" rather than "pulled" into business ownership, but more recent studies have indicated that overall many women now actively choose self-employment, specifically younger women. In a different study, Walker et al. (2008) observe that women's preference to home-based business ownership is driven predominantly by the flexibility afforded to lifestyle and the ability to balance work and family. Women entrepreneurs can significantly contribute in poverty reduction, mobilization of entrepreneurial initiatives, autonomy, and in accelerating the achievement of wider socioeconomic objectives (Belwal\& Singh, 2008). However, the contribution of women entrepreneurs depends on their performance, which in turn is affected by the underlying facilitators and barriers, understating of which is a key to nurturing a balance economy and the growth in a long run.

\section{YOUNG FEMALES IN GUJARAT AND}

Our Youths presently live in an environment predominant with the influences of parents, schools, peer groups, government policies, social values and the wave of internet related issues. All these work to shape the thinking and direction of our youths positively or negatively. In the positive sense, the mind and thought of these youths become properly and positively directed to face the issues of life, while the reverse becomes the opposite.

The need to create value in the lives of our Youths special young women has given rise to various calls for inculcating entrepreneurship skills amongst them. Since women entrepreneurship involves wealth creation leading to gainful employment and advancing society, the need therefore to strengthen entrepreneurship programmes. We are aware that if the youths are mobilized to embrace entrepreneurship it would go a long way to reduce societal crimes like armed robbery, kidnapping, drug abuse, immoral behaviours etc. 


\section{Fundamental Base}

Any youth desirous of embarking on entrepreneurship must identify with some foundational issues amongst which are:

- Determination: This is a key factor in the pursuit of any enterprise. Any youth therefore in any chosen field of endeavour must persevere to succeed.

- Mentorship: The Youths in question must have an eye to identify and study how people succeeded in life, and adopt them as role model.

- Focus: Entrepreneurial youths must remain focus and have direction, and not to wallow in ignorance. Remaining focus will enable the youth to realize his ability and talents.

- Education: Reading makes a man (says Francis Bacon, French great author). Entrepreneurial youths must attach self to studying issues bordering on entrepreneurship and applying same accordingly. The person could as well attach himself to entrepreneurial institutions for training; teaching the young people to go all out to start a business, which at the end creates sense of responsibility and self esteem.

Therefore women entrepreneurship amongst our young ones will equip them with the tools to become successful and to create prosperity for themselves and nation. These youths must have the mind of achievers. Achievers remain focused towards their planned action. They see delays and difficulties as opportunity to plan better. To them the end result is more important than the challenges on their way. To them they believe that hard work employed in their enterprise would reward them accordingly, and that such accomplishment would impact on the society, thereby growing the economy.

Again, an action oriented entrepreneur is a highly calculative individual who is always willing to undertake risks in order to achieve their goals. Economic development essentially means a 
process of upward change whereby the real per capita income of a country increases over a period of time. Entrepreneurship has an important role to play in the development of a country. It is one of the most important inputs in economic development. The number and competence of entrepreneurs affects the economic growth of the any state or region.

The crucial and significant role played by the entrepreneurs in the economic development of advanced countries has made the people of developing and underdeveloped countries conscious of the importance of entrepreneurship for economic development. It is now a widely accepted fact that active and enthusiastic entrepreneurs can only explore the potentials of the countries availability of the resources such as labour, capital and technology.

The role of entrepreneurs is not identical in the various economics or regions. Depending on the material resources, industry climate and responsiveness of the potential system, infrastructural facilities, it defers from the economy and from state to state. The contribution of entrepreneurs may be more in favourable opportunity conditions than with relatively less favourable opportunity conditions. Growing unemployment particularly educated unemployment is the problem of the nation. The available employment opportunities can cater only 5 to 10 percent of the unemployed educated youths. In fact, entrepreneurs generate employment both directly and indirectly. Directly through self employment as an entrepreneur and indirectly by starting many industrial units they offer jobs to many people. Thus entrepreneurship is one best way to fight the problems of unemployment and bring a change towards the economic empowerment of the people. On this line the following framework is developed for this study.

\footnotetext{
Perception of Capital and Physical Infrastructure Based Entry Barriers
} 


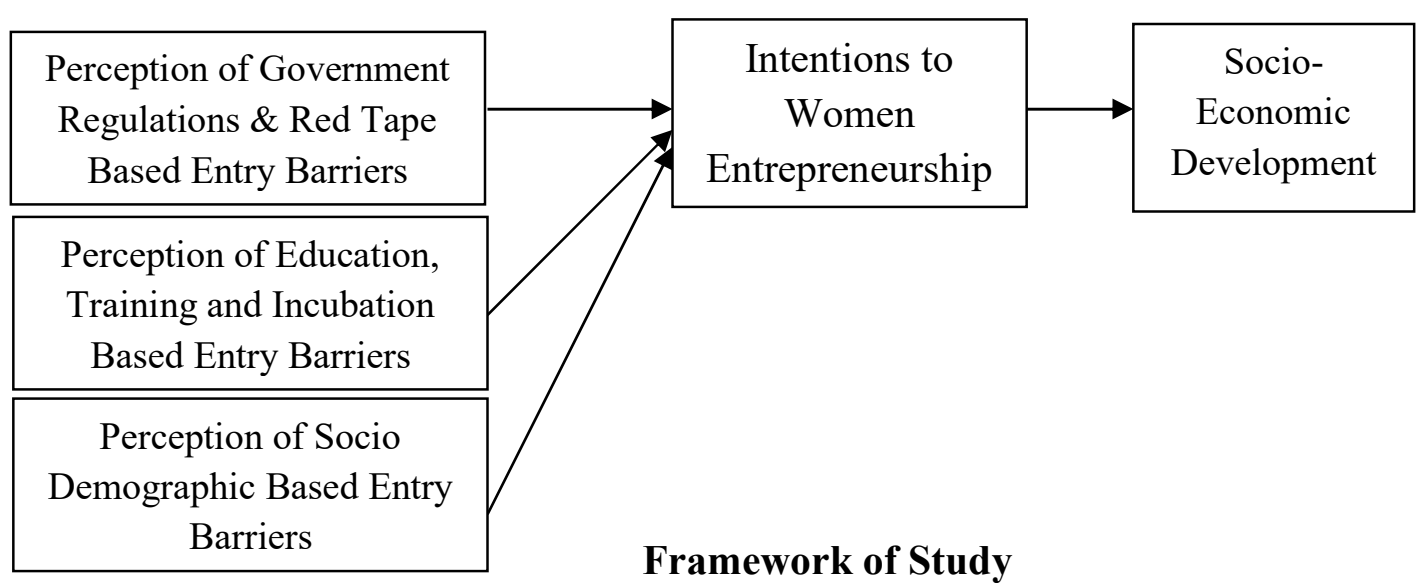

The study may help in identifying measures to remove such barriers from the minds of the people because without the entrepreneurship the economic development of the region is not fulfilled in its true sense. The study may give in this way a great help to the policy makers, planners, trainers, agencies, and the academia at large in their future initiatives for the overall economic welfare of this region.

\section{RESEARCH QUESTIONS:}

Women entrepreneurship has been recognized as one of the important untapped source of economic growth. Women entrepreneurs create new jobs for themselves and for others as well. However, they still represent minority of all entrepreneurs. The low level of motivation to enter into entrepreneurship activity and identifying its root causes has become very significant as women entrepreneurship is directly associated with women empowerment. The purpose of the proposed research thus is to understand the perception of the young women about the barriers to being an entrepreneur. The study will address the following research questions and coverage:

1. What factors they perceive inhibit the young women from starting their entrepreneurial ventures?

2. How could we improve the participation of women in the entrepreneurial ventures?

3. What are the major issues to be focused upon by the government as policy incentives to empower women? 
Finally, the proposed study will explore the level of interest and perception of young women about entrepreneurship and reasons for inhibition to enter into entrepreneurship. This study will give benefits to the policy makers and planners for taking up appropriate strategy for a long term economic development of the people in this region and our country in general.

\section{OBJECTIVES OF STUDY}

1. To study the entry barriers to entrepreneurship as perceived by the young women in Gujarat.

2. To analyze the career preference and its influencing factors of the women under study in Gujarat.

3. To explore the perception about the possible support system required by the young women for the establishment of entrepreneurship in the areas under study.

4. To study the awareness of policies, programmes, institutional networks and support agencies in promoting women's entrepreneurship in Gujarat.

\section{Research Methodology:}

The present study has been conducted among young women Gujarat. The Study covers both urban and rural areas of these two regions. For the said purpose, young women from 26 districts of Gujarat has been interviewed. As per plan, it is targeted to cover atleast 50 young women from each district. The study is a descriptive in nature.

\section{Research Approach}

The study uses both qualitative as well as quantitative approach for data collection and analysis.

\section{Data sources}


Data has been collected both from the primary as well as secondary sources. Primary data will be collected through personal interviews schedules and discussions with the young women. The secondary data for the study has been collected from various reports, bulletins, Internet uploads, Government publications.

\section{Sampling Method}

Out of the 26 districts of Gujarat data has been identified from each district and data will be collected from those districts.

\section{Instrument for data collection and analysis}

Data has been collected through a well designed questionnaire. Structured questionnaire including open and closed ended questions are developed. Data has been analyzed using graphical methods and descriptive statistics as per the requirements.

\section{Data Analysis:}

For analyzing the perception of barriers to entrepreneurship, appropriate statistical tools has been used and the same has been using R software.

\section{Analysis and Conclusion :}

The SEM modelling revealed that perception of female entrepreneurs and socio-cultural challenges has a positive and significant effect on the adoption of social media and financial challenges have a positive but statistically insignificant effect. The moderating effect of the socio-cultural challenge has been found positive and insignificant, and the moderating effect of financial challenges has been found positive and significant. In the business community, Facebook is an essential part of entrepreneurship activities. Young females often use Facebook in pursuance of acquiring suppliers and clients through their connections and connections of their friends. Facebook has been very famous and favourable for the women entrepreneurs and women possess an encouraging attitude towards utilization of social media, and perceive it useful, costeffective and efficient to meet with dynamic needs of the society. The outcomes of the present study suggest that financial challenges moderate the effect of perception of young females on the adoption of social media significantly. However, this challenge has become a turning point for 
them to avail opportunities, expand the business, and get support from the government and other state institutions through effective utilization of social media platforms. Hence, financial challenges have been affecting women positively and encourage them to adopt social media platforms.

It is found that factors like socio-cultural are positively but insignificantly moderates the effect of perception of women entrepreneurs on the adoption of social media. More than financial challenges awareness and adoption of the schemes, follow processes for application for funding are problems to female entrepreneurs.

\section{Theoretical and Practical Significance}

The findings of the study has helped to the agencies that are supporting the cause of women entrepreneurship development in our country. The intervention strategies for the entrepreneurial growth can be taken up as per its findings. These agencies may include the Directorate of Commerce and Industry, the Ministry of Micro Small and Medium Enterprises, and even the educational and training institutions which are focusing on capacity building programmes in our society and nation at large.

Again, the findings of the study is of great value to the bankers and financial institutions as it can formulate the intervention strategies for better financial inclusion and in the process, embrace the willing women entrepreneurs in the list of bankable customer. The avenues are explored through this study will motivate the existing women entrepreneurs and the aspirants to involve in the activities to women entrepreneurship development for the society as whole.

The State and the Central Governments as well as various communities dealing with entrepreneurship development in the region are benefited in planning various changes and new areas of vocational training to be provided to the youth and aspirant women entrepreneurs.

The study certainly contribute towards entrepreneurial thoughts \& development and will also serve as an important literature to academicians, research scholars and the public in general who are dealing or interested in the field of entrepreneurship. 
Towards Excellence: An Indexed, Refereed \& Peer Reviewed Journal of Higher Education / Dr. Nilam Panchal/ Page 471-489

Dec, 2020. VOL.12. ISSUE NO. 5 


\section{References}

- Adamson, D. Walking the High-Tech High Wire: The Technical Entrepreneur's Guide to Running a Successful Enterprise. McGraw-Hill, 1994.

$\circ \quad$ Baird. M.L. Engineering your Start-up: A Guide for the High-Tech Entrepreneur. Professional Publications, 2003.

- Bhide, A. The Origin and Evolution of New Businesses. Oxford University Press, 2003.

- Birley, S., and D. Muzyka, eds. Mastering Entrepreneurship. Pitman, 2000.

- Boston, Thomas, and Catherine Ross. The Inner City. Transaction Publishers, 1997.

○ Brown, S.L., and K.M. Eisenhardt. Competing on the Edge: Strategy as Structured Chaos. Harvard Business School Press, 1998.

- Bygrave, W.D., and A.L. Zacharakis, eds. The Portable MBA in Entrepreneurship. 4th edition. Wiley, 2010.

○ Cristol, Steven, and Peter Sealey. Simplicity Marketing. Simon and Schuster, 2007.

○ Drucker, P. Innovation and Entrepreneurship. 2Rev Ed edition. Butterworth-Heinemann, 2010.

- Hopkins, Bruce. A Legal Guide to Starting and Managing a Nonprofit Organization. 3rd edition. Wiley, 2000.

○ Jensen, Bill. Simplicity: The New Competitive Advantage in a World of More, Better, Faster. Perseus, 2001.

- Kaplan. Jerry. Startup: A Silicon Valley Adventure. Replica Books, 2001.

- Kotler, Philip, and Alan Andreasen. Strategic Marketing for Nonprofit Organisations. 6th edition. Prentice Hall, 2002.

○ Lovins, Amory, Hunter Lovins, and Paul Hawken. Natural Capitalism: The Next Industrial Revolution. 2nd edition. Earthscan, 2005.

- Moore, Mike. A World Without Walls: Freedom, Development, Free Trade and Global Governance. Reissue edition. Cambridge: Cambridge UP,2007

- Reinhardt, Forest. Down to Earth. Harvard Business School Press, 2000.

- Shulman, J. and T. Stallkamp. Getting Bigger by Growing Smaller. Prentice Hall Financial Times, 2003.

- Smith, Bucklin and Associates. The Complete Guide to Nonprofit Management. 2nd edition. Wiley, 2000. 
- Southwick, K. Silicon Gold Rush. Wiley, 1999.

- Spinelli, S., Birley, S. and R. Rosenberg. Franchising: Pathway to Wealth. Prentice HallFinancial Times, 2003.

- Spinelli, S., and J. Timmons. New Venture Creation for the 21st Century. 9th edition. McGraw-Hill, 2012.

- Thomas Robert J., ed. New Product Success Stories: Lessons from Leading Innovators. Wiley, 1995.

- Vesper, K. New Venture Experience. Vector Books, 1996.

- Zahra, S., ed. Contemporary Issues in Strategic Management Research. Information Age Publishing, 2002.

- Christy, Ron. The Complete Information Bank for Entrepreneurs and Small Business Managers. Center for Entrepreneurship and Small Business Management, Wichita State University, 1988.

- Cohen, William. The Entrepreneur and Small Business Problem Solver: an Encyclopedic Reference and Guide. 3rd edition. Wiley, 2005.

- Sahlman, William A., Howard H. Stevenson, Michale J. Roberts, and Amar Bhide, eds. The Entrepreneurial Ventures. Harvard Business School Press, 1999.

- Timmons, Jeffrey A., Andrew Zacharakis, and Stephen Spinelli. Business Plans That Work: A Guide for Small Business. Revised Edition. McGraw-Hill, 2011.

- Solomon, George T., Susan Duffy, and Ayman Tarabishy. "The State of Entrepreneurship Education in the United States: A Nationwide Survey and Analysis." International Journal of Entrepreneurship Education 1:1 (2002), 65-86.

○ Kent, C.A. Entrepreneurship Education. New York: Quorum Books, 1990.

- Acs, Zoltan J. and David B. Audretsch, eds. Handbook of Entrepreneurship Research: An Interdisciplinary Survey and Introduction. 2nd Edition. Springer, 2011.

- Katz, Jerome A. and Robert H. Brockhaus, Sr., eds. Advances in Entrepreneurship, Firm Emergence and Growth. JAI Press.

- Kent, Calvin A., Donald L. Sexton, and Karl H. Vesper, eds. The Encyclopedia of Entrepreneurship. Englewood Cliffs, NJ: Prentice-Hall, 1982.

- Landstrom, Hans, Hermann Frank, and Jose Veciana, eds. Entrepreneurship and Small Business Research in Europe: An ECSB Survey. Ashgate Publishing Co., 1997. 
- Libcap, Gary, ed. Advances in the Study of Entrepreneurship, Innovation, and Economic Growth. University of Arizona. JAI Press.

- Sexton, Donald L. and Hans Landstrom, eds. The Blackwell Handbook of Entrepreneurship. Blackwell, 2000.

- Sexton, Donald L. and Raymond W. Smilor, eds. Entrepreneurship 2000. Chicago: Upstart Blishing Co., 1997.

- Sexton, Donald L. and John D. Kasarda, eds. The State of the Art of Entrepreneurship. Boston: PWS-Kent Publishing Co., 1992.

- Sexton, Donald and Raymond W. Smilor, eds. The Art and Science of Entrepreneurship. Cambridge, MA: Ballinger Publishing Co., 1986.

- Shane, Scott A. "Who is Publishing the Entrepreneurship Research." Journal of Management (1997) Vol. 23, Pages 83-95.

○ Thornton, Patricia H. "The Sociology of Entrepreneurship." Annual Review of Sociology; Palo Alto: Annual Reviews, Inc. 1999.

\section{Dr. Nilam Panchal}

Associate Professor \& Head- Department of Public Policy and Governance B.K. School of Professional and Management Studies Gujarat University nilamcpanchal@gmail.com, M.9726676890 